\title{
Impact of parasitic infection on human gut ecology and immune regulations
}

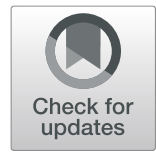

Ahsan Naveed ${ }^{*+}$ and Sabahat Abdullah ${ }^{\dagger}$

\begin{abstract}
The human body harbors trillions of microbes collectively known as microbiota. The human gut microbiota is importantly involved in most of the human metabolic and regulatory pathways. The gut microbiota needs to be balanced for the health of the host. Several factors are involved in the distribution of microbiota in the human body, in most cases these microbiotas are commensals, but some circumstances lead to serious disorders and the development of infections from microbiota. When parasites colonize the gut, the balance between the host and the gut microbiota can be disturbed. Parasitic invasion in the gut is associated with unhygienic conditions including contaminated food and water. Parasitic invasion in the gut induces the immune response to recognize and eliminate pathogens. The current study highlights the immune system's response to disruption of normal intestinal microbiota and parasitic infections.
\end{abstract}

Keywords: Microbiota, Parasite, Entamoeba histolytica, Toxoplasma gondii, Immune system, Gut microflora

\section{Background}

The human gut harbors a diverse microbiome composed of bacteria, archaea, viruses, and parasites that are important to the well-being of the host. Intestinal parasites are important both medically and economically. Interactions among the constituents of the intestinal microbiota influence the host's immune system in the development of the disease. Effective immune mechanisms against gut parasites and their regulation are important factors to human health and stability. Neglect in any of the components of the intestinal microbiota can lead to an unhealthy intestinal ecosystem which is often manifested by disease. This article sought to present various aspects of the host-bacterium-parasite relationship and their effects on gut ecology.

\section{Gastrointestinal microbiota}

The human body consists of over 100 trillion symbiotic microbes, commonly referred to as human microbiota. Microbiota is meaningfully associated with human health and

\footnotetext{
* Correspondence: ahsannaveed.uaf@gmail.com

${ }^{\dagger}$ Ahsan Naveed and Sabahat Abdullah contributed equally to this work. Institute of Microbiology, University of Agriculture Faisalabad, Faisalabad, Pakistan
}

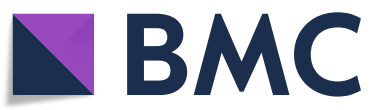

(c) The Author(s). 2021 Open Access This article is licensed under a Creative Commons Attribution 4.0 International License, which permits use, sharing, adaptation, distribution and reproduction in any medium or format, as long as you give

appropriate credit to the original author(s) and the source, provide a link to the Creative Commons licence, and indicate if changes were made. The images or other third party material in this article are included in the article's Creative Commons licence, unless indicated otherwise in a credit line to the material. If material is not included in the article's Creative Commons licence and your intended use is not permitted by statutory regulation or exceeds the permitted use, you will need to obtain permission directly from the copyright holder. To view a copy of this licence, visit http://creativecommons.org/licenses/by/4.0/. disease through a variety of mechanisms [1]. This microbiota occurs in various parts of the human body such as the skin, respiratory tract, gastro-intestinal tract, and urinary tract [2]. Most of the intestinal microbiota is found in the colon and contains a variety of bacteria, some archaea, viruses, fungi, and some parasites, including protists and helminthes [3]. Firmicutes, Bacteroidetes, Actinobacteria, Proteobacteria, Fusobacteria, and Verrucomicrobia are the most common gut microbial phyla, with Firmicutes and Bacteroidetes [4] accounting for $90 \%$ of gut microbiota. Lactobacillus, Bacillus, Clostridium, Enterococcus, and Ruminicoccus are among the more than 200 genera that make up the Firmicutes phylum. Clostridium genera account for $95 \%$ of all isolates. Bacteroidetes includes well-known genera like Bacteroides and Prevotella. The Actinobacteria phylum has a smaller proportion of bacteria and is dominated by the Bifidobacterium genus [5].

Despite the growing interest in the scientific community for this subject, as evidenced by the number of dedicated papers in the scientific literature, only about $30 \%$ of the human GI microbiota has been characterized [6]. The human microbiota is critical to humans because it acts as a physical barrier against foreign pathogens and plays an important role in developing the immune 
system [7]. Gastrointestinal microbiota, contains genes that are found throughout the human body's genome and are considered "essential organs." These genes of gut microbiota are significantly more metabolic than those found in the rest of the genome of human and are linked to different biochemical pathways through several specific enzymes [8]. The gut microbiota serves a variety of functions, including producing enzymes not found in humans for digestion and fermentation of unused energy substrates, vitamins such as biotin and vitamin $\mathrm{K}$, and hormones that guide the host to store fats. Significant progress suggests that some human biological processes are regulated by the intestinal microbiota, such as regulation of epithelial development, modulation of metabolic phenotype and influence of innate immunity [9]. Several factors, such as age, diet, gender, gastrointestinal infections, antibiotic use, smoking and stress, influence the distribution of the microbiota among individuals [10]. The parasites which inhabit the human intestinal tract are commensal as well as harmless such as Entamoeba dispar and Pentatrichomonas [11]. Some organisms and/or biota disequilibria (dysbiosis) are thought to be capable of causing infections under some circumstances. Gastrointestinal parasites upset in some rare cases, most importantly, Blastocystis sp. or Dientamoeba fragilis [12]. Irritable bowel syndrome, polyposis and colorectal cancer, necrotizing enterocolitis, Crohn's disease, functional dyspepsia, and other GI diseases have all been linked to changes in microbial composition [13].

\section{Risk factors associated with the onset of parasitic infection}

Parasitic infections of the gastro-intestinal tract are most often associated with poor sanitary conditions and can be transmitted by contaminated food and water sources by sewage [14]. Poverty is a major factor in parasitic infections that are commonly associated with unhygienic eating habits, including unwashed raw vegetables, poor drainage systems, and poor personal habits $[15,16]$.. Other risk factors for parasite infections include poor environmental conditions, such as living in congested homes with insufficient spacing. Contaminated water users are at high risk of pests such as Giardia and Entamoeba. Various living conditions, public settlement, and community economic well-being all contribute to infection rates [17]. Another important factor that is significantly associated with the incidence of infection is the incidence of superinfection, in which the hosts that help the parasite are re-exposed to the same parasitic pressure after the failure of precautionary measures [18]. Use of night soil is common practice in communities that cannot afford to buy commercial fertilizers for their crops as a result the agricultural land gets contaminated. The association between parasite transmission and night soils as fertilizers has been observed in several studies [19].
Polyparasitism is also considered an important factor, since hosts with multiple infections due to multiple diseases have an increased risk of susceptibility to further infections [20]. Intestinal infections with helminthes are associated with increased episodes of malaria and coinfection with Plasmodium falciparum and hookworms, which intensifies iron deficiency anemia [21]. In polyparasitism, intestinal parasites compete for nutrients that lead to malnutrition and ongoing damage to the intellectual and physical development of the individual [22].

The children suffering from coinfection of T. trichiura and $A$. lumbricoides are at greater risk of stunting growth. The consumption of un-boiled water elevates the risk of intestinal parasitic infections particularly Cryptosporidium and Giardia parasites [23]. Furthermore, epidemics of waterborne diseases due to the use of contaminated water by sewage have been described elsewhere [24].

\section{Development of parasites into the human gut}

Parasites have been shown to influence a variety of behaviors in their hosts, such as feeding and reproduction. Physiological pathways such as hormones and neurotransmitters play a role in these shifts. In this way, the host's behavioral changes can be seen as the product of a complex communication network between macro and microorganisms. Presence of specific bacterial communities should influence parasite establishment, and parasites can alter the bacterial microbiota composition. This bidirectional relationship is possible if both groups compete for similar host resources, such as a certain nutrient or ecological niche, or if the presence of parasites activates the host's immune response, disrupting different homeostatic relationships formed between the bacterial microbiota and its host. Even though different individuals, even within the same population, may have a wide range of microbial species, it has been established that the gut microbiota has some ecological stability. This property of gut microbiota stability is essential for host health and well-being because it ensures that beneficial symbionts and their functions are preserved over time [25].

Parasitic infections are not uncommon among humans and more than 1 billion people are affected by parasitic infections. Parasites account for over $15 \%$ of all cancers [26]. Indeed, every man on a shift is infected by a parasitic infection [27]. Amongst parasites, helminthes and protozoa primarily infect humans. Helminth being multicellular parasites cannot multiply in humans, while protozoa are unicellular and can multiply in the human body. In developing countries, helminthes and protozoa both make a significant contribution to parasitic infections, while in developed countries protozoa are more common and cause gastrointestinal infections [28]. 
Helminthes are worms containing many cells and among the helminthes, trematodes (flat worms), nematodes (round worms) and cestodes (tapeworms) are the most common that reside in the human gut. Some species of helminthes are transmitted from the soil or are known as biohelminthes: Trichuris trichiura (whipworm), Ascaris lumbricoides (roundworm), Ancylostoma duodenale, and Necator americanus (hookworms) [29]. This species of parasitic helminthes significantly helps in gastrointestinal infections. Intestinal helminthes rarely cause death but significantly affect the health and nutritional status of the host [30].

The species of intestinal protozoan parasites that cause intestinal infections are Entamoeba histolytica, Cryptosporidium spp., Cyclospora cayetanensis, and Giardia intestinalis. These intestinal protozoans cause serious diseases including amoebiasis, cryptosporidiosis, cyclosporiasis, and giardiasis, respectively [31].

\section{Impact of parasites on gut ecology}

There is a balance in both the human body and the gut microbiota to restore human health. Any disturbance in the structure of the gut microbiota helps in the development of various diseases. The development of various inflammatory diseases such as diabetes, allergies, obesity, and inflammatory bowel disease are linked to changes in the microbiome [32]. Therefore, the commensal microbes act as a barrier for the pathogen invasion and play a key role in protecting the host from disease. The balance between intestinal microbiota and the host depends on the interaction of intestinal parasites and gut microbiota. In the gastrointestinal tract, microbial byproducts affect the physiology and survival of parasites, leading to various parasitic infections. On the other hand, the intestinal parasites including protozoa and helminthes constantly secrete and excrete the molecules that alter the gut environment for microbiota [33].

Most studies have ignored the effects of parasitic protozoa (Blastocystis spp., Giardia intestinalis, Entamoeba spp., Cryptosporidium spp., etc.) and metazoa (roundworms, whipworms, pinworms, threadworms, hookworms, and tapeworms) on human BGM because of the unique characteristics of developed countries, where evolution is thought to have reduced the infections. Healthy diet, increased hygiene, food sterilization, and antibiotics have largely reduced the number of parasite-infected individuals and the diversity of the gut microbiota. When compared to the few studies conducted in non-industrialized equivalents, it is understood that the parasite load in the population of industrialized countries affects the diversity of the BGM [34]. It is still unknown whether the effect of these changes increased BGM diversity in non-industrialized countries versus lower diversity in industrialized countries is beneficial to an individual's overall health [35].

Host invasion mechanisms vary greatly between protozoa, some protozoa acting as intracellular (Cryptosporidium spp.), Some adapting to more than one host (Giardia duodenales), while others host specific (Entamoeba histolytica). Presence of normal flora in the gut reduces the vulnerability to infection by Cryptosporidium parvum [36]. On the other hand, gut microbiota significantly contributes to certain enteric parasitic infections by Blastocystis hominis, E. histolytica and various species of Eimeria [37]. Different mechanisms (make a list and examples in each) are involved in the pathogenic stimulation of parasites by bacteria. Giardia duodenales is a very common gastrointestinal protozoa in humans as well as in animals, and its disease spectrum varies from mild illness to chronic or acute diarrhea. Giardia infection in people often leads to gut dysfunction even after the infection is cleared up [38]. Bacteria residing in the gut influence the pathogenicity and proliferation of Giardia in humans e.g., Lactobacillus which slows its growth [39]. Pathogenic strains of E. coli and S. dysenteriae significantly augment the virulence of Entamoeba histolytica by enhancing the cysteine activity and expression of Gal/GalNAc lectin on the amoebic surface [40].

When it comes to the impact of helminth infections on the microbiota, parasite species do not appear to be a good predictor of how bacterial population composition or diversity will change after infection, as study results can vary even within single host-parasite systems. Parasites seem to be capable of acting as ecosystem engineers for gut microbes by modifying the physical environment in which they live. Existing research indicates that the types of effects seen by parasitic helminths and protozoa could be somewhat different. While helminths can improve barrier function and restrict bacterial translocation, virulent parasitic protozoa can have the opposite effect, deteriorating barrier function and allowing bacteria and the epithelium to interact more closely [41].

In the case of helminths, it is estimated that over 1 billion people are infected by soil-transmitted helminths such as Ascaris lumbricoides and Trichuris trichiura, among others. In humans, a study published in 2017 in Sri Lanka found that gut microbiota diversity is associated with helminth infection [42]. It is well known that helminthic parasites secrete a variety of excretory-secretory products, including immunomodulatory proteins, glycoproteins, and microRNAs, which influence the function of various cell types, including regulatory immune cells. Helminths have such a profound impact on the immune system that they have been used for medicinal purposes [43]. Infection with $G$. intestinalis in humans is thought to cause long-term changes in commensal microorganisms, facilitating bacterial invasiveness in the gut mucosa during 
the post-clearance process. Damage to the epithelial barrier causes an unresolved immune response in the host to its microbiota, according to a study conducted in mice. In 2016, a study of Blastocystis spp., Entamoeba spp., and Giardia intestinalis in a human population found a grouping division between Giardia-infected individuals and those infected with other parasites, suggesting that the microbial communities could be reshaped solely by the existence of Giardia parasites. These findings indicate that protozoa parasites, including helminths, alter the composition of the human bacterial gut microbiota [44]. It has been documented that infection of Heligmosomoides polygyrus in mice affects the Lactobacillae spp. in ileum [45]. Studies have also evidenced that Trichuris suis significantly affects the microbiota of pigs in colon [46]. The abundance of Lactobacilli in the small intestine is due to the presence of $H$. polygyrus bakeri [47].. In addition to this Schistosoma mansoni, Necator americanus, Fasciola hepatica, and other helminthes parasites pose a great threat to the composition of gut microbiota [48]. Table 1 is summarizing the effect of various parasitic mechanism on gut environment. The role of helminthes in modulating the gut microbiota cannot be neglected. Gut helminthes may secrete a verity of products for modulation of microbial growth in the gut or they may compete with gut microbes for nutrients. In either case, gut helminthes leave their impact on the host [49].

\section{The immune mechanism in the gastrointestinal tract}

Intestine cells such as enterocytes, goblet cells, Paneth cells, neuroendocrine and tuft cells together with the intestinal epithelial cells and intercellular tight junctions act as an essential barrier to prevent the breaching of pathogens into the gut [50]. Epithelial cells recognize bacterial products such as LPS through the expression of nucleotide-binding oligomerization domain-like receptors and Toll-like receptors. Epithelial cells also release the alarmins as cytokines that are required to stimulate dendritic cells as well as innate lymphoid cells to respond to physical invasion and trauma.

Epithelial cells that are particularly involved in helminth infections are Paneth cells, goblet cells, and tuft cells. Goblet cells are involved in the secretion of mucus, which acts as a barrier between the epithelium and pathogens [51]. Paneth cells in the small intestine play a dual role: they are responsible for the release of antimicrobial molecules, including phospholipase, lysozyme and antimicrobial defensins, as well as nourish the adjacent stem cells of the intestine [52]. Tuft cells plays a significant role in anti-helminth immunity, through the release of alarmin IL-25 [53]. Tuft cells require Pouf3, a transcription factor for differentiation of cells and Pouf3 knockout mice lacking are not able to expel helminth from intestine unless IL-25 is administered exogenously [54].

The release of alarmins during the helminth infections and production of Th2 cytokines stimulates the regression of epithelial fluid as well as muscle peristalsis, providing a model of "weep and sweep" for the expulsion of the intestinal helminthes. Along with this mast cell proteases damage tight junctions that permit the intestinal fluid to leak into the lumen and contraction of smooth muscles effectively sweep the helminthes away [55].

\section{Immune response to protozoal infections}

Most the protozoa do not cause disease, but in some cases, they are detrimental to human and animal health. Here we focused on the key protozoal parasites, Entamoeba histolytica and Toxoplasma gondii.

Entamoeba histolytica is protozoa associated with the gut, causing amoebiasis that affects people worldwide. Infections are asymptomatic but, in some circumstances, it invades the host epithelium. Survival of E. histolytica within the host is facilitated by its virulence factors [56]. Virulence factors of E. histolytica (cysteine proteases, Gallectin, peroxiredoxin, and lipopeptidophosphoglycan) also play a role in activating host's immune system [57]. Gallectin facilitates the binding of E. histolytica to the mucosal matrix and cleaves the mucin by using cysteine proteases which leads $E$. histolytica towards intestinal epithelial cells [58]. Mucus in the intestinal tract prevents amoeba from entering the intraepithelial cells and provides the first line of defense [59]. In addition to mucin, secretory immunoglobulin A (sIgA) and antimicrobial compounds

Table 1 Various mechanisms adopted by parasites and its consequences on gut ecology

\begin{tabular}{|c|c|c|}
\hline Mechanism adopted by parasites & Consequences & Examples \\
\hline Helminthes and protozoa can increase the mucus production & Enhance mucolytic bacterial production & T. suis, Eimeria \\
\hline Change in mucus composition & $\begin{array}{l}\text { Decreased bacterial attachment to gut } \\
\text { epithelium }\end{array}$ & $\begin{array}{l}\text { Giardia, Entamoeba histolytica, } T \text {. } \\
\text { gondii }\end{array}$ \\
\hline $\begin{array}{l}\text { Secrete a variety of excretory-secretory products, including immu- } \\
\text { nomodulatory proteins, glycoproteins, and microRNAs }\end{array}$ & $\begin{array}{l}\text { Influence the function of various cell types, } \\
\text { including regulatory immune cells }\end{array}$ & $\begin{array}{l}\text { Ascaris lumbricoides and Trichuris } \\
\text { trichiura }\end{array}$ \\
\hline Long-term changes in commensal microorganisms & $\begin{array}{l}\text { Facilitating bacterial invasiveness in the gut } \\
\text { mucosa during the post-clearance process }\end{array}$ & G. intestinalis \\
\hline Pose a great threat to the composition of gut microbiota & May compete with gut microbes for nutrients & $\begin{array}{l}\text { Schistosoma mansoni, Necator } \\
\text { americanus, Fasciola hepatica }\end{array}$ \\
\hline
\end{tabular}


(REG1) present in intestinal tract also protect against $E$. histolytica infection [60].

If amoeba succeeds in breaching the initial luminal barrier, then intraepithelial cells respond to E. histolytica infection. The recognition of LPPG on E. histolytica by IECs induces the production of various cytokines and chemokines (IL-6, GM-CSF, and TNF-alpha), which facilitate the recruitment of monocytes as well as neutrophils [61]. Death of intraepithelial cells leads to inflammation; neutrophils are instantly recruited to the site of infection to combat the infection [62].

Macrophages express Toll-like receptor (TLR) that recognizes the various virulence factors of $E$. histolytica and trigger an immune response. DNA of amoeba is recognized by TLR9 and LPPG is recognized by TLR2 and TLR4 [63]. When activated by cytokines (IFN-gamma), macrophages produce nitric oxide, which inhibits cytotoxicity of E. histolytica infection [64]. Activation of dendritic cells by TLRs promotes the production of cytokine as well as the expression of costimulatory molecules (CD40, CD80, and CD86) [65]. Natural killer and natural killer $\mathrm{T}$ cells do not provide intestinal immunity but are important in preventing the colonization of amoeba in the liver. These cells activate the innate immune cells (neutrophils and macrophages) by secreting TNF-alpha and IFN-gamma. Deficiency of NK T-cells leads to the colonization of amoeba in the liver and liver abscesses, similarly, deficiency of NOS or IFN-gamma leads to severe liver infection, indicating the significance of these cytokines [66].

Regarding adaptive immunity, Th1 responses also contribute to protecting against $E$. histolytica infection. Patients with asymptomatic infection exhibited high levels of IFN-gamma, indicating a protective role of Th1 responses. Whereas patients with invasive amoebiasis showed high levels of IL-4, a cytokine associated with Th2 [67]. IL-4 production is important in susceptibility and pathogenicity of infection, while IFN-gamma production plays an important role in protecting against infection. A balance between the Th1 and Th2 responses is critical in the prevention of E. histolytica infection [68].

Toxoplasma gondii is causative agent of toxoplasmosis, a parasitic infection worldwide. It easily transmits to humans by ingestion of spores released from feces. Both adaptive and innate immune components play an important role in protecting against $T$. gondii infections [69]. Deficiency of certain cytokines, including IL-12, IFN-gamma, and iNOS, enhances the susceptibility to $T$. gondii infections [70]. Once T. gondii binds to the intestinal mucosa, immune response gets activated by the Toll-like receptors in dendritic cells. Various TLRs (2, 3, 4, 7 and 9) are involved in T. gondii infection [71]. T. gondii profilin, a major parasitic ligand, has been recognized by dimer TLR11/12. Upon recognition of profiling, transcription factor, interferon (IFN) regulatory factor 8 get activated and then leads to the production of interleukin 12 (IL-12). This interleukin induces the production of IFN-gamma from natural killer cells and provokes the differentiation of Th1 lymphocytes.

$\mathrm{T}$ cells play an integral role in protecting against $T$. gondii infections. Deficiency of $\mathrm{T}$ cells in mice can leads to death due to an uncontrollable proliferation of parasite in different organs, including the brain. Both CD4+ and CD8+ $\mathrm{T}$ cells contribute to the prevention of infection by secreting the IFN-gamma [72]. Mice deficient in IFN-gamma lead to severe acute inflammation following the necrotic lesions in the brain. In contrast to other protozoan infections, IL-4 plays a significant protective role in protecting against $T$. gondii infections. IL-4 facilitates the Th2 cell differentiation as mice lacking IL-4 exhibit very fewer IFN-gamma producing T cells [73].

\section{The immune response to helminthes}

Intestinal helminthes are the most prevalent parasites in humans and other mammals. Helminth infections are dominated by Type 2 response and activation of immune regulatory network that involves trapping, killing, and expelling parasites [74]. These immune responses reduce the number of parasites harboring the intestinal tract. As well as protects against infection by repairing tissue damage caused by parasitic colonization in the tissues [75]. The immune response is initiated by the induction of cytokines IL-4, IL-5, IL-9 and IL-13 that activate various downstream mechanisms required to combat helminth infections [76]. The key cytokines involved in this response are IL-4 and IL-13 and their signaling is done by STAT6 and IL-4Ra [77]. These cytokines act on the epithelial cells of the intestine and stimulate the differentiation of goblet cells as well as augment the production of mucus [78]. Increased fluid flow into the lumen and contraction of intestinal muscles facilitate the worms to get flushed out of the gut [79].

In chronic helminth infections, peripheral $\mathrm{T}$ cells do not respond to various parasitic antigens [80]. In addition to type 2 response, the various immune components involved in limiting helminth infections are regulatory $\mathrm{B}$ cells, regulatory $\mathrm{T}$ cells, and activated type 2 macrophages [81]. These type 2 macrophages play an integral role in the immune response using the effector molecules such as TIMP1 and TIMP2, arginase-1 and IGF-1, which significantly stimulate the fibroblast and myofibroblast matrix formation [82]. T-regulatory cells play a dual role in helminth infections, reducing the protective immunity that leads to the development of chronic infections and protects the host from the extreme inflammatory response to infections [83]. T- regulatory cells express transcription factor Forkhead box P3 (Foxp3) and any mutation in this gene leads to IPEX 
syndrome (immune dysregulation, polyendocrinopathy, enteropathy, X-linked syndrome) along with inflammation in the gastrointestinal tract [84]. T-regulatory cells interact with the cell surface and release TGF-beta and IL-10, which significantly suppress both Th1 and Th2 cells. The dependence of helminthes on regulatory compartment shows that helminthes induce the development of Tregs which modulates the immune response [85].

The evolution of the immune response is against helminth infections. Schistosomiasis is a typical example of evolution in immune response because in this case the earlier Th1 response has been replaced by the Th2 immune response as soon as the parasite begins to release the eggs [86]. Primarily in helminth infections, the immune response is triggered by the Th1, Th2, and Th17 CD4+ cells to limit the infection to mucosal surfaces that leads to robust inflammation. If this immune response fails to succeed and leads to latent infection, then Th2 reaction mediated by IL-4, IL-5, Th2 CD4+ cells, and eosinophils get involved, which together reduce parasitic load [87]. During chronic infection, the immunomodulatory immune response mediated by antiinflammatory cytokines and regulatory cells (IL-10, TGF-beta) ensures minimum levels of helminthes [88]. Immunomodulatory responses are affected differently during different phases of infection [89].

\section{Protective role of parasites in autoimmune diseases}

Exaggerated antibody reactions to harmless antigens, such as those from benign aquatic species or our own bodies, cause allergic and autoimmune disorders. The debate has emerged as to whether parasites dampen their host's immune system to facilitate their own longevity while also preventing immunopathology-causing overreactions. Half of the known species to date are pathogenic parasites. Among microparasites gastrointestinal nematodes are one of most common and having significant impact on life and health. Those organisms reveal strong, specific immune response in host, involving primary mechanisms associated with regulatory and Th2 cells. Referring to immunomodulatory abilities of helminths, parasite infections started to be considered as a possible therapy for many autoimmune diseases.

The loss of parasite invasion of people living in developing countries has had a unique effect on our immune system, and it is likely the most important factor leading to the progression of autoimmune disease, along with genetic predisposition. While it is still a new area, small clinical trials have also been conducted to determine the effects of Trichuris suis, a porcine whipworm, on IBD (Inflammatory Bowel Disease). Initial pilot tests using oral intake of live $T$. suis ova at frequent intervals suggested that it could help with IBD without causing any obvious side effects. In Crohn's patients, a related experiment is being conducted, this time using the human hookworm Necator americanus [90].

Helminth-infected patients have changes in immune responsiveness that are both quantitative and qualitative, indicating that the parasite is exploiting the host immune system or that the host is reaching out to the parasite. In chronically infected filariasis and schistosomiasis patients, antigen-specific $\mathrm{T}$-cell reactivity was observed to be depressed, but reactivity could be restored after chemotherapeutic cure of infection, suggesting that the involvement of helminths deliberately suppresses host immunity [91].

Rheumatoid arthritis (RA) is a painful and crippling systemic disease involving innate and adaptive immune systems, especially Th1 cell activity and the release of inflammatory cytokines such as TNF. The development of an immunologically healthy condition because of helminth infection is thought to mitigate the incidence of an autoimmune rheumatic disorder that is present. A deeper understanding of the anti-inflammatory mechanisms triggered by helminth infection or their secretory products is remained elusive $[92,93]$.

\section{Conclusion}

Besides the above-mentioned factors, ignorance of hygiene measures and insufficient information about sanitation, predisposes the individuals to intestinal parasitic infections. Finally, intestinal parasitic infections are a serious health threat among individuals. Although, the immune system responds well to parasitic infection, but measures should be adopted to reduce the risk of infections either through immunization or development of anti-parasitic drugs. Health education campaigns, particularly for children, should be employed to ensure proper hygiene habits to prevent the infections. Measures should be taken to promote awareness of hygiene and health interventions, including sanitation, improving economic status, hygiene education, and intermittent pesticides.

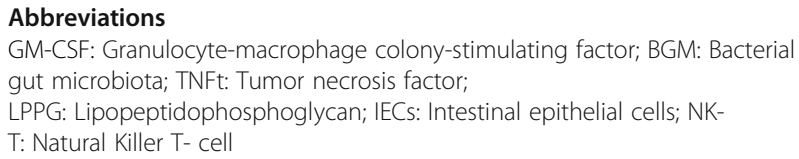

\section{Acknowledgments}

We feel gratitude in acknowledging Professor Dr. Sajjad Ur Rahman, Director Institute of Microbiology, University of Agriculture, Faisalabad, Pakistan, for his continuous guidance.

Authors' contributions

The author(s) read and approved the final manuscript.

Funding

No funding source was available.

Availability of data and materials Not Applicable. 


\section{Declarations}

Ethics approval and consent to participate

Not Applicable.

\section{Consent for publication}

Not Applicable.

\section{Competing interests}

The authors declare that they have no competing interests.

\section{Received: 4 February 2021 Accepted: 11 May 2021}

Published online: 26 May 2021

\section{References}

1. Wang $B$, Mingfei $Y$, Longxian $L$, et al. The human microbiota in health and disease Engineering. 2017;3(1):71-82. https:/doi.org/10.1016/J.ENG.2017.01.008.

2. Dave M, Higgins PD, Middha S, Rioux KP. The human gut microbiome: current knowledge, challenges, and future directions. Transl Res. 2012;160(4): 246-57. https://doi.org/10.1016/j.trsl.2012.05.003.

3. Wawrzyniak I, Poirier P, Viscogliosi E, Dionigia M, Texier C, Delbac F, et al. Blastocystis, an unrecognized parasite: an overview of pathogenesis and diagnosis. Ther Adv Infect Dis. 2013;1(5):167-78. https://doi.org/10.1177/204 9936113504754

4. Arumugam M, Raes J, Pelletier E, Le Paslier D, Yamada T, Mende DR, et al. Enterotypes of the human gut microbiome. Nature. 2011;473(7346):174-80. https://doi.org/10.1038/nature09944.

5. Rinninella $E$, Raoul $P$, Cintoni $M$, et al. What is the healthy gut microbiota composition? A changing ecosystem across age, environment, diet, and diseases. Microorganisms. 2019;7(1):14. https://doi.org/10.3390/microorga nisms7010014.

6. Lagier JC, Armougom F, Million M, Hugon P, Pagnier I, Robert C, et al. Microbial culturomics, paradigm shift in the human gutmicrobiome study. Clin Microbiol Infect. 2012;18(12):1185-93. https://doi.org/10.1111/14690691.12023

7. Bouskra D, Brézillon C, Bérard M, Werts C, Varona R, Boneca IG, et al. Lymphoid tissue genesis induced by commensals through NOD1 regulates intestinal homeostasis. Nature. 2008;456(7221):507-10. https://doi.org/10.103 8/nature07450

8. Bogitsh BJ, Carter CE and Oeltmann (2012) TN. Human parasitology. Academic Press, 4th Edition 448.

9. Barratt $J$, Harkness J, Marriott D, et al. A review of Dientamoeba fragilis carriage in humans: several reasons why this organism should be considered in the diagnosis of gastrointestinal illness. Gut Microbes. 2011; 2(1):3-12. https://doi.org/10.4161/gmic.2.1.14755.

10. O-Toole PW. Changes in the intestinal microbiota from adulthood through to old age. Clin Microbiol Infect. 2012;18:44-6. https://doi.org/10.1111/j.14 69-0691.2012.03867.x.

11. Ursell LK, Haiser HJ, Treuren WW, et al. The intestinal metabolome: an intersection between microbiota and host. Gastroenterol. 2014;146(6):14706. https://doi.org/10.1053/j.gastro.2014.03.001.

12. Pérez-Cobas AE, Artacho A, Knecht H, Ferrús ML, Friedrichs A, Ott SJ, et al. Differential effects of antibiotic therapy on the structure and function of human gut microbiota. PLoS One. 2013;8(11):e80201. https://doi.org/10.13 71/journal.pone.0080201

13. Blaser M, Falkow S. What are the consequences of the disappearing human microbiota? Nat Rev Microbiol. 2009;7(12):887-94. https://doi.org/10.1038/ nrmicro2245.

14. Chaves EM, Vazquez L, Lopes K, Flores J, et al. Levantamento de Protozoonoses e Verminoses nas sete creches municipais de Uruguaiana, Rio Grande do Sul - Brasil. Rev Bras de ana Clin. 2006;38:39-41.

15. Tappe KH, Mohammadzadeh $\mathrm{H}$, Khashaveh S, et al. Prevalence of intestinal parasitic infections among primary school attending students in BarandoozChay rural region of Urmia, West Azerbaijan province, Iran in Africa. J Med Res 2011. 2008:5:788-91.

16. Sejdini A, Mahmud R, L-Lim YA, et al. Intestinal parasitic infection among children in Central Albania. Ann Trop Med Paras. 2011;105(3):241-50. https://doi.org/10.1179/136485911X12987676649584.

17. Mehraj V, Hatcher J, Akhtar S, Rafique G, Beg MA. Prevalence and factors associated with intestinal parasitic infection among children in an urban slum of Karachi. PLoS One. 2008;3(11):e3680. https://doi.org/10.1371/journal. pone.0003680

18. Ng JV, Belizario WY Jr, Claveria FG. Determination of soil-transmitted helminth infection and its association with hemoglobin levels among Aeta schoolchildren of Katutubo Village in Planas, Porac, and Pampanga. Phil Sci Lett. 2014;7:73-80.

19. Zheng Q, Chen Y, Zhang HB, Chen JX, Zhou XN. The control of hookworm infection in China. Parasit Vectors. 2009;2(1):44. https://doi.org/10.1186/1 756-3305-2-44.

20. Al-Delaimy AK, Al-Mekhlafi HM, Nasr NA, et al. Epidemiology of intestinal polyparasitism among orang Asli school children in rural Malaysia. PLoS Neg Trop Dis. 2014;8:3074.

21. Hurlimann E, Yapi RB, Houngbedji CA, et al. The epidemiology of polyparasitism and implications for morbidity in two rural communities of cote d'Ivoire. Para Vectors. 2014;7(1):81. https://doi.org/10.1186/1756-3305-7-81.

22. Saldiva SR, Silveira AS, Philippi ST, et al. Ascaris-Trichuris association and malnutrition in Brazilian children. Paediatr. Perinat Epidemiol. 1999:13(1):8998. https://doi.org/10.1046/j.1365-3016.1999.00145.x.

23. Anuar TS, Al-Mekhlafi HM, Ghani MK, et al. Giardiasis among different tribes of orang Asli in Malaysia: highlighting the presence of other family member's infected with Giardia intestinalis as a main risk factor. Int J Parasit. 2012;42(9):871-80. https://doi.org/10.1016/j.jpara.2012.07.003.

24. Choy SH, Al-Mekhlafi HM, Mahdy MA, et al. Prevalence and associated risk factors of Giardia infection among indigenous communities in rural Malaysia. Sci Rep. 2014:4:6909.

25. Carrillo RE, Gaona O, Nieto J, et al. Disturbance in human gut microbiota networks by parasites and its implications in the incidence of depression. Sci Rep. 2020;10:3680. https://doi.org/10.1038/s41598-020-60562-w.

26. Benamrouz S, Conseil V, Creusy C, Calderon E, Dei-Cas E, Certad G. Parasites and malignancies, a review, with emphasis on digestive cancer induced by Cryptosporidium parvum (Alveolata: Apicomplexa). Parasite. 2012;19(2):10115. https://doi.org/10.1051/parasite/2012192101.

27. Tong HV, Brindley PJ, Meyer CG, et al. Parasite infection, carcinogenesis, and human malignancy. E Bio Med. 2017:15:12-23.

28. Haque R. Human Intestinal Parasites. J Health Popul Nutr. 2007;25:387-91.

29. Savioli L, Albonica M. Soil-transmitted helminthiasis. Nat Rev Microbiol. 2004; 2(8):618-9. https://doi.org/10.1038/nrmicro962.

30. Cappello M. Global health impact of soil-transmitted nematodes. Pediatr Infect Dis J. 2004;23(7):663-4. https://doi.org/10.1097/01.inf.0000132228. 00778.e4.

31. Davis AN, Haque R, Petri WA Jr. Update on protozoan parasites of the intestine. Curr Opin Gastroenterol. 2002;18(1):10-4. https://doi.org/10.1097/ 00001574-200201000-00003.

32. Spor A, Koren O, Ley R. Un-raveling the effects of the environment and host genotype on the gut microbiome. Nat Rev Microbiol. 2011;9(4):279-90. https://doi.org/10.1038/nrmicro2540.

33. Sekirov L, Russell SL, Antunes LCM, et al. Gut microbiota in health and disease. Physiol Rev. 2010;90(3):859-904. https://doi.org/10.1152/physrev. 00045.2009

34. Chabé M, Lokmer A, Ségurel L (2017) Gut Protozoa: friends or foes of the human gut microbiota? Trends Parasitol 33(12):925-934. doi: https://doi. org/10.1016/j.pt.2017.08.005. Epub 2017 Sep 1. PMID: 28870496.

35. Sankar SA, Lagier JC, Pontarotti P, Raoult D, Fournier PE (2015) The human gut microbiome, a taxonomic conundrum. Syst Appl Microbiol 38: 276-286. doi: https://doi.org/10.1016/j.syapm.2015.03.004. Epub 2015 Mar 25. PMID: 25864640, 4

36. Guk SM, Yong TS, Park JH, Chai JY. Gnotype and animal infectivity of a human isolate of cryptosporidium parvum in the Republic of Korea. Korean J Parasitol. 2004;42(2):85-9. https://doi.org/10.3347/kjp.2004.42.2 85.

37. Pawlowski SW, Cirle AW, Richard G. Diagnosis and treatment of acute or persistent diarrhea. Gastroenterol. 2009;136(6):1874-86. https://doi.org/10.1 053/j.gastro.2009.02.072

38. Burgess SL, Gilchrist CA, Lynn TC, et al (2017) Parasitic protozoa and interactions with the host intestinal microbiota. Infect Immun 85: pii: e00101-17.

39. Clemente JC, Ursell LK, Parfrey LW, Knight R. The impact of the gut microbiota on human health: an integrative view. Cell. 2012;148(6):1258-70. https://doi.org/10.1016/j.cell.2012.01.035.

40. Galvan-Moroyoqui JM, Dominguez-Robles MD, Franco E, et al. The interplay between Entamoeba and Enteropathogenic Bacteria 
modulates epithelial cell damage. PLoS Negl Trop Dis. 2008;2(7): e266. https://doi.org/10.1371/journal.pntd.0000266.

41. Leung JM, Graham AL, Knowles SCL. Parasite-microbiota interactions with the vertebrate gut: synthesis through an ecological Len. Front Microbiol. 2018;9:843. https://doi.org/10.3389/fmicb.2018.00843.

42. Jenkins TP, Rathnayaka Y, Perera PK, Peachey LE, Nolan MJ, Krause L, Rajakaruna RS, Cantacessi C (2017) Infections by human gastrointestinal helminths are associated with changes in fecal microbiota diversity and composition. PLoS One. 12(9): e0184719. Published 2017 Sep 11. doi: https://doi.org/10.1371/journal.pone.0184719.

43. Sipahi AM, Baptista DM (2017) Helminths as an alternative therapy for intestinal diseases. World J Gastroenterol;23(33):6009-6015. doi: https://doi. org/10.3748/wjg.v23.i33.6009. PMID: 28970717; PMCID: PMC5597493.

44. Toro-Londono MA, Bedoya-Urrego K, Garcia-Montoya GM, Galvan-Diaz AL, Alzate JF. (2019) Intestinal parasitic infection alters bacterial gut microbiota in children. PeerJ7: e6200 Published 2019 Jan 7. doi:https://doi.org/10.7717/ peerj.6200.

45. Walk ST, Blum AM, Ang-Sheng ES, et al. Alteration of the murine gut microbiota during infection with the parasitic helminth, Heligmosomoides polygyrus. Inflamm Bowel Dis. 2010;16(11):1841-9. https://doi.org/10.1002/ ibd.21299.

46. Li RW, Wu S, Li W, Navarro K, Couch RD, Hill D, et al. Alteration in the porcine colon microbiota induced by the gastrointestinal nematode Trichuris suis. Infect Immune. 2012;80(6):2150-7. https://doi.org/10.1128/IAl. 00141-12.

47. Reynolds LA, Smith KA, Filbey KJ, Harcus Y, Hewitson JP, Redpath SA, et al. Commensal-pathogen interaction in the intestinal tract lactobacilli promote infection with, and are by, helminth parasites. Gut Microbes. 2014;5(4):52232. https://doi.org/10.4161/gmic.32155.

48. Wang Y, Li JV, Saric J, et al. Advances in the metabolic profiling of experimental nematode and trematode infection. Adv Parasitol. 2010;73: 373-404. https://doi.org/10.1016/50065-308X(10)73012-8.

49. Biswal D. Helminth infections and gut microbiota: the futuristic study of pathogen virulence and gut ecosystem. J Mol Biomark Diagn. 2016;7:7-3.

50. Artis D. Epithelial-cell recognition of commensal bacteria and maintenance of immune homeostasis in the gut. Nat Rev Immunol. 2008;8(6):411-20. https://doi.org/10.1038/nri2316

51. Mccauley HA, Guasch G. Three cheers for the goblet cell: maintaining homeostasis in mucosal epithelia. Trends Mol Med. 2015;2:492-503.

52. Clevers HC, Bevins CL. Paneth cells: maestros of the small intestinal crypts. Annu Rev Physiol. 2013;75(1):289-311. https://doi.org/10.1146/annurevphysiol-030212-183744.

53. Howitt MR, Lavoie S, Michaud M, Blum AM, Tran SV, Weinstock JV, et al. Tuft cells, taste-chemosensory cells, orchestrate parasite type 2 immunity in the gut. Sci. 2016;351(6279):1329-33. https://doi.org/10.112 6/science.aaf1648

54. Gerbe F, Sidot E, Smyth DJ, Ohmoto M, Matsumoto I, Dardalhon V, et al. Intestinal epithelial tuft cells initiate type 2 mucosal immunity to helminth parasites. Nat. 2016;529(7585):226-30. https://doi.org/10.1038/nature16527.

55. Maizels RM, Hewitson JP, Smith KA. Susceptibility and immunity to helminth parasites. Curr Opin Immunol. 2012;24(4):459-66. https://doi.org/10.1016/j. coi.2012.06.003.

56. Verkerke HP, Petri WA, Marie CS. The dynamic interdependence of Amebiasis, innate immunity, and undernutrition. Semin Immunopathol. 2012;34(6):771-85. https://doi.org/10.1007/s00281-012-0349-1.

57. Guo X, Houpt E, Petri WA. Crosstalk at the initial encounter: interplay between host defense and amoeba survival strategies. Curr Opin Immunol. 2007;19(4):376-84. https://doi.org/10.1016/j.coi.2007.07.005.

58. Chadee K, Petri WA, Innes DJJ, et al. Rat and human colonic mucins bind to and inhibit adherence lectin of Entamoeba histolytica. J Clin Invest. 1987; 80(5):1245-54. https://doi.org/10.1172/JCl113199.

59. Bergstrom KSB, Kissoon-Singh V, Gibson DL, et al. Muc2 protects against lethal infectious colitis by disassociating pathogenic and commensal Bacteria from the colonic mucosa. PLoS Path. 2010;6:1000902.

60. Peterson KM, Guo X, Elkahloun AG, Mondal D, Bardhan PK, Sugawara A, et al. The expression of REG $1 \mathrm{~A}$ and REG $1 \mathrm{~B}$ is increased during acute amebic colitis. Parasitol Int. 2011;60(3):296-300. https://doi.org/10.1016/.jpa rint.2011.04.005.

61. Becker SM, Kyou-Nam C, Guo X, et al. Epithelial cell apoptosis facilitates Entamoeba histolytica infection in the gut. Am J Path. 2010;176(3):1316-22. https://doi.org/10.2353/ajpath.2010.090740.
62. Rivero-Nava L, Aguirre-García J, Shibayama-Salas M, et al. Entamoeba histolytica: acute granulomatous intestinal lesions in normal and neutrophildepleted mice. Exp Parasitol. 2002;101(4):183-92. https://doi.org/10.1016/ S0014-4894(02)00106-6.

63. Ivory CPA, Prystajecky M, Jobin C, Chadee K. Toll-like receptor 9-dependent macrophage activation by Entamoeba histolytica DNA. Infect Immun. 2008; 76(1):289-97. https://doi.org/10.1128//Al.01217-07.

64. Karl B, Seydel KB, Smith SJ, et al. Innate immunity to amebic liver abscess is dependent on gamma interferon and nitric oxide in a murine model of disease. Infect Immun. 2000;68:400-2.

65. Vivanco-Cid H, Alpuche-Aranda C, Wong-Baeza I, et al. Lipopopeptide phosphoglycan from Entamoeba histolytica activates human macrophages and dendritic cells and reaches their late endosomes. Parasite Immunol. 2007;29(9):467-74. https://doi.org/10.1111/j.1365-3024.2007.00963.x.

66. Lotter H, Roldan GN, Lindner B, et al. Natural killer T cells activated by a Lipopeptidophosphoglycan from Entamoeba histolytica are critically important to control amebic liver abscess. PLoS Path. 2009;5:1000434.

67. Guo X, Stroup SE, Houpt ER. Persistence of Entamoeba histolytica infection in CBA mice owes to intestinal IL-4 production and inhibition of protective IFN-gamma. Mucosal Immunol. 2008; (2):139-46. https://doi.org/10.1038/ mi.2007.18.

68. Sanchez-Guillen MC, Pérez-Fuentes R, Salgado-Rosas H, et al. Differentiation of entamoeba histolytica/entamoeba dispar by PCR and their correlation with humoral and cellular immunity in individuals with clinical variants of amoebiasis. Am J Trop Med Hyg. 2002;66(6):731-7. https://doi.org/10.4269/a itmh.2002.66.731.

69. Flegr J, Prandota J, Sovičková M, Israili ZH. Toxoplasmosis - a global threat. Correlation of latent toxoplasmosis with specific disease burden in a set of 88 countries. PLoS One. 2014;9(3):e90203. https://doi.org/10.1371/journal. pone.0090203.

70. Yarovinsky F, Zhang D, Andersen JF, Bannenberg GL, Serhan CN, Hayden MS, et al. TLR11 activation of dendritic cells by a protozoan profilin-like protein. Sci. 2005;308(5728):1626-9. https://doi.org/10.1126/science.1109893.

71. Yarovinsky F. Innate immunity to toxoplasma gondii infection. Nat Rev Immunol. 2014;14(2):109-21. https://doi.org/10.1038/nri3598.

72. Schluter $D$, Hein A, Dorries $R$, et al. Different subsets of $T$ cells in conjunction with natural killer cells, macrophages, and activated microglia participate in the intracerebral immune response to toxoplasma gondii in athymic nude and immunocompetent rats. Am J Patho. 1995;146:999-1007.

73. Shaw MH, Reimer T, Sanchez-valdepenas C, et al. T cell intrinsic role of node in promoting type 1 immunity against toxoplasma gondii. Nat Immunol. 2009;10(12):1267-74. https://doi.org/10.1038/ni.1816.

74. Maizels RM, Balic A, Gomez-Escobar N, et al. Helminth parasite-masters of regulation. Immunol Rev. 2004;201(1):89-116. https://doi.org/10.1111/j.01 05-2896.2004.00191.x.

75. Allen JE, Wynn TA. Evolution of the immunity: a rapid repair response to tissue destructive pathogen. PloS Path Dio. 2004;7(5):e1002003. https://doi. org/10.1371/journal.ppat.1002003.

76. Pulendran B, Artis D. New paradigms in type 2 immunity. Sci. 2012; 337(6093):431-5.

77. Oshea JJ, Plenge R. Jaks and stats in immmunoregulation and immunemediated disease. Immunity. 2012;36(4):542-50. https://doi.org/10.1016/j. immuni.2012.03.014.

78. Artis D, Grencis RK. The intestinal epithelium: sensors to effectors in nematode infection. Mucosal Immunol. 2008;1(4):252-62. https://doi.org/1 0.1038/mi.2008.21

79. Grencis RK, Humphreys NE, Bancroft AJ. Immunity to gastrointestinal nematodes: mechanisms and myths. Immunol Rev. 2014;260(1):183-205. https://doi.org/10.1111/imr.12188.

80. Mcsorley HJ, Maizels RM. Helminth infections and host immune regulation. Clin Microbiol Rev. 2012;25(4):585-608. https://doi.org/10.1128/CMR.05040-11.

81. Van Dyken SJ, Locksley RM. Interleukin-4 and interleukin-13 mediated alternatively activated macrophages: roles in homeostasis and disease. Annu Rev Immunol. 2013;31(1):317-43. https://doi.org/10.1146/annurev-immunol$032712-095906$.

82. Kron MA, Metwali A, Jankovic SV, et al. Nematode aspaaginyl-tRNA synthetase resolves intestinal inflammation in mice with T-cell transfer colitis. Clin Vacc Immunol. 2013;20(2):276-81. https://doi.org/10.1128/CVI. 00594-12

83. Sawant DV, Gravano DM, Vogel P, Giacomin P, Artis D, Vignali DAA. Regulatory $T$ cell limit induction of protective immunity and promote 
immune pathology following intestinal infection. J Immunol. 2014;192(6): 2904-12. https://doi.org/10.4049/jimmunol.1202502.

84. Bacchetta R, Passerini L, Gambineri E, Dai M, Allan SE, Perroni L, et al. Defective regulatory and effector cell function in patients with FOXP3 mutation. J Clin Invest. 2006;1 16(6):1713-22. https://doi.org/10.1172/JCI25112.

85. Gringer JR, Smith KA, Hewitson JP, et al. Helminth secretion induce de novo T cell Foxp3 expression and regulatory function through the TGF- $\beta$ pathway. J Exp Med. 2006;207:2331-41.

86. Pearce EJ, Macdonald AS. The immunobiology of schistosomiasis. Parasite Immunol. 2002;2:499-511.

87. Thomas B, Nutman MD. Looking beyond the induction of the responses to explain immunomodulation by helminthes. Parasite Immunol. 2015;37:304-13.

88. Elliott $D E$, Weinstock JV. Nematodes and human therapeutic trials for inflammatory disease. Parasite Immunol. 2017;39:12407.

89. Lopes F, Matisz C, Reyes $J$, et al. Helminth regulation of immunity: a threepronged approach to treat colitis. Inflamm Bowel Dis. 2017;22:2499-512.

90. Zaccone P, Fehervari Z, Phillips JM, Dunne DW, Cooke A. Parasitic worms and inflammatory diseases. Parasite Immunol. 2006;28(10):515-23. https:// doi.org/10.1111/j.1365-3024.2006.00879.x.

91. Maizels RM. Parasitic helminth infections and the control of human allergic and autoimmune disorders. Clin Microbiol Infect. 2016;22(6):481-6. https:// doi.org/10.1016/j.cmi.2016.04.024.

92. Oliveiraa SM, Gomides APM, Motab LMH, Limad CMBL, Rochaf FAC. Intestinal parasites infection: protective effect in rheumatoid arthritis? Rev Bras Reumatol. 2017;57(5):461-5.

93. Apaer S, Tuxun T, Ma HZ, Zhang H, Aierken A, Aini A, et al. Parasitic infection as a potential therapeutic tool against rheumatoid arthritis (review). Exper Ther Med. 2016;12(4):2359-66. https://doi.org/10.3892/etm.2 016.3660 .

\section{Publisher's Note}

Springer Nature remains neutral with regard to jurisdictional claims in published maps and institutional affiliations.

Ready to submit your research? Choose BMC and benefit from:

- fast, convenient online submission

- thorough peer review by experienced researchers in your field

- rapid publication on acceptance

- support for research data, including large and complex data types

- gold Open Access which fosters wider collaboration and increased citations

- maximum visibility for your research: over $100 \mathrm{M}$ website views per year

At $\mathrm{BMC}$, research is always in progress.

Learn more biomedcentral.com/submissions 